\title{
Longitudinal study into the determining factors of dental caries in children aged 4: socio-behavioral aspects and oral health of pregnant women
}

\author{
Estudo longitudinal sobre determinantes da cárie aos 4 anos de idade: aspectos sócio-comportamentais e saúde \\ bucal da gestante
}

\author{
Najara Barbosa ROCHA ${ }^{1}$ \\ Cléa Adas Saliba GARBIN ${ }^{1}$ \\ Artênio José Isper GARBIN¹ \\ Orlando SALIBA' \\ Suzely Adas Saliba MOIMAZ1
}

\section{ABSTRACT}

\section{Objective}

To analyze the influence of oral health conditions and socio-behavioral characteristics of pregnant women on the development of caries and their children's experiences, after 4 years of follow-up.

\section{Methods}

It was conducted a longitudinal study of mother/child pairs by interview and oral clinical examination during pregnancy. Regular observations were made until the child had reached four years of age, at which time we performed a clinical examination of the children ( $n=73$ ). The variables studied were: presence of caries in pregnancy (DMFT) and the child (deft), visit to the dentist, oral hygiene habits, diet, socioeconomic and behavioral factors, and were related to two study outcomes: presence of caries during the examination and experience of caries (deft $\geq 1$ ) in children of 4 years of age. Bivariate and logistic regression analyses were conducted with the variables $(p<0.05$ and $95 \% \mathrm{Cl})$.

\section{Results}

The average DMFT index of mothers during pregnancy was $12.09( \pm 2.88)$ and average deft index of children at 4 years was $1.79( \pm 6.1)$. In the multiple logistic regression analysis, the presence of caries in children was associated with the presence of harmful habits ( $p=0.04)$. Caries in the child was statistically associated with brush sharing among family members $(p=0.02)$.

\section{Conclusion}

The results suggest that behavioral aspects are related to the presence and experience of caries in childhood.

Indexing terms: Dental caries. Longitudinal studies. Oral health. Risk factors. Socioeconomic factors.

\section{RESUMO}

\section{Objetivo}

Analisar a influência das condições de saúde bucal e das características sócio-comportamentais de gestantes no desenvolvimento e na experiência de cárie em seus filhos, após 4 anos de acompanhamento.

\section{Métodos}

Foi realizado um estudo longitudinal com pares de mães e filhos, mediante entrevista e exame clínico bucal na gestação. Observações periódicas foram realizadas até os quatro anos completos de idade da criança, momento em que foi realizado o exame clínico na criança ( $n=73$ ). As variáveis estudadas foram: presença de cárie na gestante (CPOD) e na criança (ceod), visita ao cirurgião-dentista, hábitos de higiene bucal, dieta, fatores socioeconômicos e comportamentais, sendo relacionadas com dois desfechos do estudo: presença de cárie no momento do exame e experiência de cárie (ceod $\geq 1$ ) em crianças aos 4 anos de idade. Foram conduzidas análises bivariadas e multivariada com auxílio do Programa Bioestat ( $p<0,05$ e IC 95\%).

\section{Resultados}

O CPOD médio das mães durante a gestação foi $12,09( \pm 2,88)$ e ceod médio das crianças aos 4 anos foi 1,79 $( \pm 6,1)$. Na análise de regressão logística múltipla, a presença de cárie nos filhos esteve associada com a presença de hábitos deletérios $(p=0,04)$. A experiência de cárie no filho foi associada estatisticamente com o compartilhamento de escova entre os membros da família ( $p=0.02)$.

\section{Conclusão}

Os resultados sugerem que aspectos comportamentais estão relacionados à presença e experiência de cárie na infância.

Termos de indexação: Cárie dentária. Estudos longitudinais. Saúde bucal. Fatores de risco. Fatores socioeconômicos.

\footnotetext{
${ }^{1}$ Universidade Estadual Paulista Júlio de Mesquita Filho, Faculdade de Odontologia, Programa de Pós-graduação em Odontologia Preventiva e Social. Araçatuba, SP, Brasil. Correspondência para / Correspondence to: SAS MOIMAZ. E-mail: <sasaliba@foa.unesp.br>.
} 


\section{INTRODUCTION}

Dental caries remains a serious problem for public oral health in the majority of industrialized and developing countries'. In Brazil, the most recent national data on dental caries, in 2010, showed that at five years of age only $46.6 \%$ of Brazilian children were free from caries in the deciduous dentition and at 12 , a mere $43.5 \%$ in the permanent dentition ${ }^{2}$. These values show that, even with advances in the understanding of the etiology and nature of the disease, caries is still regarded as one of the most prevalent oral afflictions in infancy.

Caries should not be treated as simply a disease affecting oral health but as a social and behavioral condition, in view of its complex etiology ${ }^{3}$. Early childhood caries is so called when it involves at least one decayed, extracted or filled tooth $(\mathrm{def} \geq 1)$ in children less than 71 months old 4 .

Conceptual models have been described in order to understand the premature development of dental caries in children ${ }^{5}$. One of these models explains that the disease's predisposing factors may be linked to the child, family and community. As far as child factors are concerned, besides the genetic and biological aspects, we would highlight access to dental care, development, physical attitudes, demographics and behavior, as well as health practices. Family influences are based on socioeconomic and demographic conditions, parents' oral health, culture, health-related practices, behaviors and abilities, physical safety and family function. Turning to the community, the factors are broader, including social assistance, the characteristics of access to dental and health services, culture, social and physical environment and the oral health environment in the community ${ }^{5}$.

Although early childhood caries is recognized as being multifactorial, further clarification is needed on the interaction of the risk factors and the reason for some children suffering from the disease more than others. Influences in the early years of life may have a significant effect on the health of the deciduous and permanent dentitions ${ }^{6}$.

Early identification of key factors in oral health makes it possible to carry out primary care in pregnancy and in early infancy, with the aim of preventing diseases that harm children's development from taking root $^{3,7-9}$.

The mother's lifestyle, including habits such as sugar intake between meals, cariogenic diet during pregnancy and oral hygiene can all have an influence on the experience of caries in their children. This occurs because these undesirable habits can continue during early childhood and be harmful to the child since the parents, mainly the mothers, are responsible for their oral care.

With regard to the development of caries, some factors are known and have been well studied, such as: mother's level of schooling, family income, marital status, mother's age at time of birth, however our understanding of the influence of the child's birth weight, the mother's gestational age, place of residence, lifestyle and behavior is still limited ${ }^{7-10}$. There have been few studies ${ }^{8,10-11}$ into factors related to caries in children below the age of four and the majority ${ }^{6-7,12-16}$ are designed to study the etiology of this affliction in older, pre-school children, for example. Most of the studies $3,9,12-13,15-17$ analyzing caries in children and their oral health condition, as well as the behavioral condition of the mother, were conducted using a crosssectional design. Thus, the aim of this longitudinal study was to analyze the influence of oral health conditions and socio-behavioral characteristics of pregnant women on the development and experience of caries in their children, after 4 years of follow-up.

\section{METHODS}

This is a prospective, longitudinal study that began in 2007 with the monitoring of pregnant women in the public services of a city in the northwest of the Brazilian state of São Paulo ${ }^{18}$.

\section{Study population}

The sample was composed of pregnant women (and their children after they were born), who were included in a government program to monitor the prenatal period, amounting to 120 pairs in total. In order to calculate the sample size of the finite population, the prevalence of caries in deciduous teeth was taken into consideration, $35 \%$ according to the literature ${ }^{9}$, adopting a level of significance of $5 \%$, an absolute sampling error of $6.4 \%$ and a finite population during the period of study (March to July 2007). Those pregnant women who agreed to take part in the study by signing an informed consent form and who were in the last trimester of pregnancy and who did not have multiple births, were included in the study.

Some subjects fell by the wayside during the 4-year follow-up as they did not wish to proceed with the study $(n=13)$ while some could not be located at the address recorded during the initial interview $(n=34)$. These losses are common in this type of study ${ }^{19}$, so the 
final sample used was 73 mother/son pairs for the 4-year follow-up.

During pregnancy, the women were interviewed and examined to evaluate dental caries and periodontal disease. The children were monitored from birth by means of home visits on a periodic basis: every month up to 6 months of age, then at 12, 18, 24 and 48 months. At four years of age, they were given an oral examination and the mothers were interviewed once again.

\section{Outcome}

Two outcomes were analyzed for the study variables in order to ascertain the factors that influence the development of caries: 1) The presence or otherwise of caries in the deciduous teeth of the children studied (decayed component of the deft index) and 2) experience of early childhood caries, i.e. when it involves at least one decayed, extracted or filled tooth (deft $\geq 1$ ) in children under 71 months of age ${ }^{4}$.

\section{Clinical examination}

A pilot study $(n=15)$ was carried out using a population similar to that of the main study, for the calibration of the researchers, to adjust the data collection instruments and a clinical examination of both mother and child, with a team comprising one interviewer and one note taker. The Kappa test value for intra-rater agreement was 0.91.

\section{Data collection}

The forms used in the interviews included information about the mother's oral health, maternal habits, oral hygiene practices, daily routine, socioeconomic and demographic conditions and access to dental services. The indices used for the collection of the clinical data of the pregnant women and children followed the criteria advocated by the $\mathrm{WHO}^{20}$, using a flat mirror and a CPI probe for epidemiological evaluations, under natural light, with both examiner and patient seated.

After 4 years of follow-up, a home visit was made and the oral health of the child was recorded (deft) ${ }^{20}$, and an interview with the mothers was conducted to ascertain the habits, oral hygiene standards, behavior and characteristics of the children. The children's clinical examinations included a visual check for the presence of active white spots on the deciduous teeth, using the Visible Plaque Index, where 0 signifies the absence of visible bacterial plaque and 1 the presence of visible bacterial plaque in at least one deciduous tooth ${ }^{21}$.

\section{Studied variables}

Oral hygiene was classified as complete when toothpaste, toothbrush and dental floss were used on a daily basis. Smoking and drinking habits during pregnancy (yes/ no) were noted, questioning the pregnant woman about the use of cigarettes or alcohol one or more times per week. Income was categorized as follows: mothers receiving up to 2 minimum wages or receiving 2 minimum wages or more (minimum wage being $\mathrm{R} \$ 724$ ). Depending on the mother's age when the child was born, they were classified as: mothers aged up to 22 and those 22 years of age or older. This classification was adopted by considering mothers aged 21 and under as young mothers. As far as marital status is concerned, they were asked if they lived with their partner or not. As for level of schooling, the classification was as follows: up to 8 years of study (elementary education) and 8 years or more of study. A check was made to see if the mother had any systemic illness during pregnancy. With regard to eating habits, it was ascertained if the pregnant mother ate sweet foods or liquids between meals. Birth weight was divided into two groups: children under and over $2.5 \mathrm{Kg}$. Children were regarded as premature when born at less than 37 weeks gestation. The children's eating habits were recorded with regard to the consumption of sweet foods between meals, the intake of any liquids (milk, tea, juice, among others) with sugar in the feeding bottle and/or any liquid with sugar in the bottle at nighttime.

\section{Statistical analysis}

At the conclusion of the interviews, the questionnaires and clinical records were reviewed by the team and subsequently input to the analytical programs. The data were processed using the Epi Info 2000 software program ${ }^{22}$ analyzed using the Biostat program ${ }^{23}$, version 5.3.

The statistical analysis included a descriptive and inferential analysis at a level of significance of $p \leq 0.05$ and confidence interval $(\mathrm{Cl})$ of $95 \%$.

Multivariate analyses were conducted using Multiple Logistic Regression, with two models being adjusted for the outcome variables (decayed component present in the deft index and experience of caries) versus the study variables, which exhibited a value of $p \leq 0.20$ in the bivariate analysis ${ }^{23}$. Results were presented using frequencies and Relative Risk (RR), with a $\mathrm{Cl}$ of $95 \%$.

\section{Ethical principles}

Ethical aspects for conducting research on human beings and the Helsinki Declaration were observed as well 
as having the approval of the Human Research Committee at the Araçatuba Faculty of Dentistry (UNESP), case no. 2202/2011, and all the mothers signed a free and informed consent agreement.

\section{RESULTS}

The average age of the mothers at the time their child was born was $29.9( \pm 5.7)$ years. The majority lived with their partner $(78.1 \%)$, had completed less than 8 years of schooling (89.0\%), had more than one child $(60.3 \%)$ and a family income of less than 2 minimum wages (89.0\%). Most of the mothers (74.0\%) did not suffer from any systemic illness and consumed sugar in their diets during pregnancy $(68.5 \%)$. A total of 43 children $(58.9 \%)$ were female, 62 (84.9\%) weighed more than $2.5 \mathrm{Kg}$ at birth and 58 (79.4\%) were born after 37 weeks gestation. The majority of children had sugar in their feeding bottles (58.9\%), food containing sugar between meals (87.7\%) and nighttime bottles with sweet liquids (56.2\%). Only 10 children $(13.7 \%)$ had seen a dentist, though the majority $(65.8 \%)$ of mothers did clean their children's teeth at least once a day using a comforter, gauze or brush.
Table 1. Distribution of the caries index (DMFT and dmft) components of the mother and child, according to the mean of each component and its total. Araçatuba (SP), 2013.

\begin{tabular}{ccccc}
\hline DMFT & Mean & SD & Median & $\%$ \\
\hline Decayed & 2.57 & \pm 2.98 & 2.00 & 21.2 \\
Missing & 2.49 & \pm 3.80 & 1.00 & 20.6 \\
Filled & 7.03 & \pm 5.46 & 7.50 & 58.2 \\
Total & 12.09 & \pm 6.10 & 12.00 & 100.0 \\
\hline dmft & Mean & SD & Median & $\%$ \\
\hline Decayed & 1.46 & \pm 2.70 & 0.00 & 81.6 \\
Missing & 0.03 & \pm 0.23 & 0.00 & 1.7 \\
Filled & 0.30 & \pm 0.87 & 0.00 & 16.7 \\
Total & 1.79 & \pm 2.88 & 0.00 & 100.0 \\
\hline
\end{tabular}

The average DMFT for the mothers was 12.09 $( \pm 6.10)$, the filled element being the most prevalent in pregnant women (58.2\%). The average deft in children was $1.79( \pm 2.88)$, the decayed element being the most prevalent $(81.5 \%)$ (table 1$)$.

The presence of caries in the mother was not linked to the presence of caries in the child, nor the experience of early childhood caries, as shown in tables 2 and 3 .

Tables 2 and 3 show the results of the bivariate analysis of the behavioral, social, economic and demographic aspects and the mother and child's oral

Table 2. Numerical and percentual mother's distribution, according to presence of dental caries in the children and variables, Araçatuba (SP), 2013.

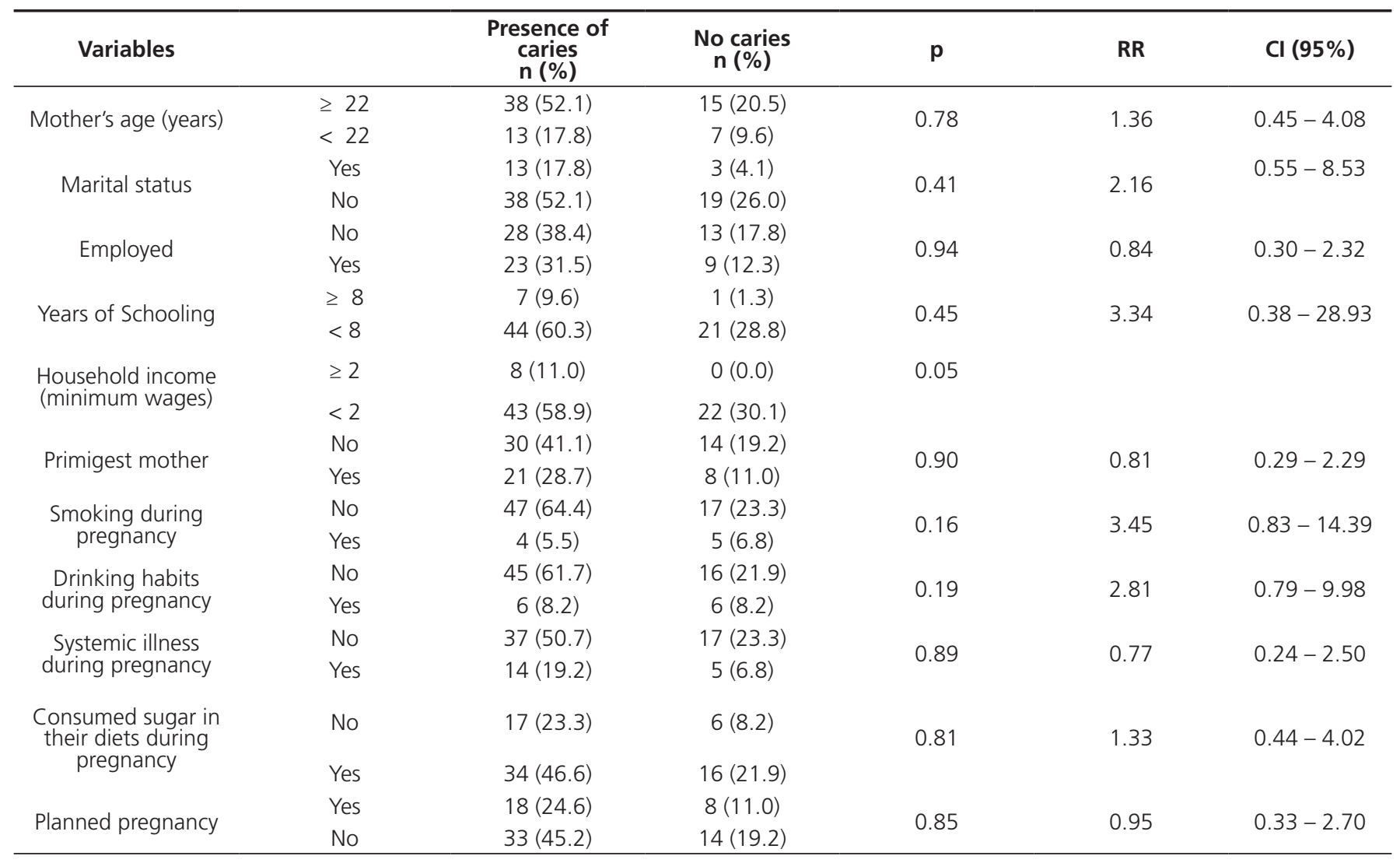




\begin{tabular}{|c|c|c|c|c|c|c|}
\hline \multirow{2}{*}{$\begin{array}{l}\text { Complete oral } \\
\text { hygiene }\end{array}$} & Yes & $26(35.7)$ & $6(8.2)$ & \multirow{2}{*}{0.10} & \multirow{2}{*}{2.77} & \multirow{2}{*}{$0.93-8.22$} \\
\hline & No & $25(34.2)$ & $16(21.9)$ & & & \\
\hline \multirow{2}{*}{$\begin{array}{l}\text { The mother went to } \\
\text { the dentist }\end{array}$} & Yes & $14(19.2)$ & $8(11.0)$ & \multirow{2}{*}{0.63} & \multirow{2}{*}{0.66} & \multirow{2}{*}{$0.22-1.91$} \\
\hline & No & $37(50.6)$ & $14(19.2)$ & & & \\
\hline \multirow{2}{*}{$\begin{array}{l}\text { Presence of caries in } \\
\text { the mother }\end{array}$} & No & $16(21.9)$ & $4(5.5)$ & \multirow{2}{*}{0.38} & \multirow{2}{*}{2.05} & \multirow{2}{*}{$0.59-7.06$} \\
\hline & Yes & $35(47.9)$ & $18(24.7)$ & & & \\
\hline \multirow{2}{*}{ Mother's lost teeth } & No & $19(26.0)$ & $7(9.6)$ & \multirow{2}{*}{0.85} & \multirow{2}{*}{1.27} & \multirow{2}{*}{$0.44-3.67$} \\
\hline & Yes & $32(43.9)$ & $15(20.5)$ & & & \\
\hline \multirow{2}{*}{ DMFT } & $\leq 6$ & $8(11.0)$ & $4(5.5)$ & \multirow[b]{2}{*}{0.93} & \multirow{2}{*}{0.83} & \multirow{2}{*}{$0.22-3.13$} \\
\hline & $>6$ & $43(58.9)$ & $18(24.6)$ & & & \\
\hline \multirow{2}{*}{$\begin{array}{l}\text { Oral Health } \\
\text { Education }\end{array}$} & Yes & $11(15.1)$ & $1(1.4)$ & \multirow{2}{*}{0.14} & \multirow{2}{*}{5.77} & \multirow{2}{*}{$0.69-47.83$} \\
\hline & No & $40(54.7)$ & $21(28.8)$ & & & \\
\hline \multirow{2}{*}{ Birth weight (Kg) } & $\geq 2.5$ & $43(58.9)$ & $19(26.0)$ & \multirow{2}{*}{0.89} & & \\
\hline & $<2.5$ & $8(11.0)$ & $3(4.1)$ & & 0.84 & $0.20-3.55$ \\
\hline Gestational age & $\geq 37$ & $42(57.6)$ & $16(21.9)$ & & & \\
\hline (weeks) & $<37$ & $9(12.3)$ & $6(8.2)$ & 0.53 & $1 . / 5$ & $0.53-5.11$ \\
\hline Child'c Gender & Female & $28(38.4)$ & $15(20.5)$ & 2 & & \\
\hline chila s Gender & Male & $23(31.5)$ & $7(9.6)$ & 0.42 & 0.56 & $0.19-1.02$ \\
\hline The mother shares & No & $19(26.0)$ & $8(11.0)$ & & & \\
\hline $\begin{array}{l}\text { the cutlery with the } \\
\text { child }\end{array}$ & Yes & $32(43.8)$ & $14(19.2)$ & 1.03 & 0.84 & $0.36-2.93$ \\
\hline The sharing of & No & $39(53.4)$ & $20(27.4)$ & & & \\
\hline $\begin{array}{l}\text { tootnbrusnes by } \\
\text { family members }\end{array}$ & Yes & $12(16.4)$ & $2(2.8)$ & 0.26 & 0.32 & $0.06-1.59$ \\
\hline Child's access to the & Yes & $8(11.0)$ & $2(2.7)$ & 070 & & \\
\hline dentist & No & $43(58.9)$ & $20(27.4)$ & 0.10 & 1.86 & $0.36-9.5 /$ \\
\hline Oral hygiene of the & Yes & $33(45.2)$ & $15(20.5)$ & & & \\
\hline child & No & $18(24.7)$ & $7(9.6)$ & 0.98 & 0.85 & $0.29-2.48$ \\
\hline Presence of active & No & $28(38.4)$ & $10(13.7)$ & & & \\
\hline $\begin{array}{l}\text { White spots on the } \\
\text { deciduous teeth }\end{array}$ & Yes & $23(31.5)$ & $12(16.4)$ & 0.62 & 1.46 & $0.53-3.98$ \\
\hline $\begin{array}{c}\text { Food containing } \\
\text { sugar between meals }\end{array}$ & No & $8(11.0)$ & $1(1.3)$ & 0.35 & 3.90 & $0.45-33.32$ \\
\hline & Yes & $43(58.9)$ & $21(28.8)$ & & & \\
\hline Sugar in feeding & No & $21(28.7)$ & $9(12.4)$ & 081 & 101 & $0.36-279$ \\
\hline bottles & Yes & $30(41.1)$ & $13(17.8)$ & & & $0.50-2.19$ \\
\hline Nighttime bottles & No & $21(28.7)$ & $11(15.1)$ & 0.65 & 0.7 & $0.25-2.50$ \\
\hline with sweet liquids & Yes & $30(41.1)$ & $11(15.1)$ & & & \\
\hline Presence of harmful & No & $22(30.1)$ & $17(23.3)$ & 0.01 & 0.22 & $0.07-0.69$ \\
\hline habits & Yes & $29(39.8)$ & $5(6.8)$ & 0.01 & 0.22 & $0.07-0.09$ \\
\hline & $\leq 6$ & $26(35.6)$ & $4(5.5)$ & & & \\
\hline $\begin{array}{l}\text { Breastteeding } \\
\text { (months) }\end{array}$ & $6<12$ & $10(13.7)$ & $4(5.5)$ & 0.01 & & \\
\hline & $\geq 12$ & $15(20.5)$ & $14(19.2)$ & & & \\
\hline
\end{tabular}

health linked to the presence of caries and early childhood caries (deft $\geq 1$ ). The presence of harmful habits, i.e. sucking pacifiers or thumbs (0.01), the duration of breastfeeding $(p=0.01)$ and family income $(p=0.05)$ were linked to the presence of caries in the child. The sharing of toothbrushes by family members was linked to the experience of early childhood caries ( $p=0.01)$.

The Multiple Logistic Regression information is shown in table 4 . In terms of the link to the presence of childhood caries, this analysis included the following variables: oral health education, mother's hygiene, family income, mothers who smoke, ingestion of alcoholic beverages, presence of habits and duration of breastfeeding. As regards the association with the experience of early childhood caries (deft $\geq 1$ ) the following were included: presence of white spots on the teeth, complete oral hygiene of the mother and shared toothbrushes. 
Table 3. Numerical and percentual distribution of mothers, according to experience of early childhood caries ( $\mathrm{dmft} \geq 1)$ in the children and variables, Araçatuba (SP), 2013.

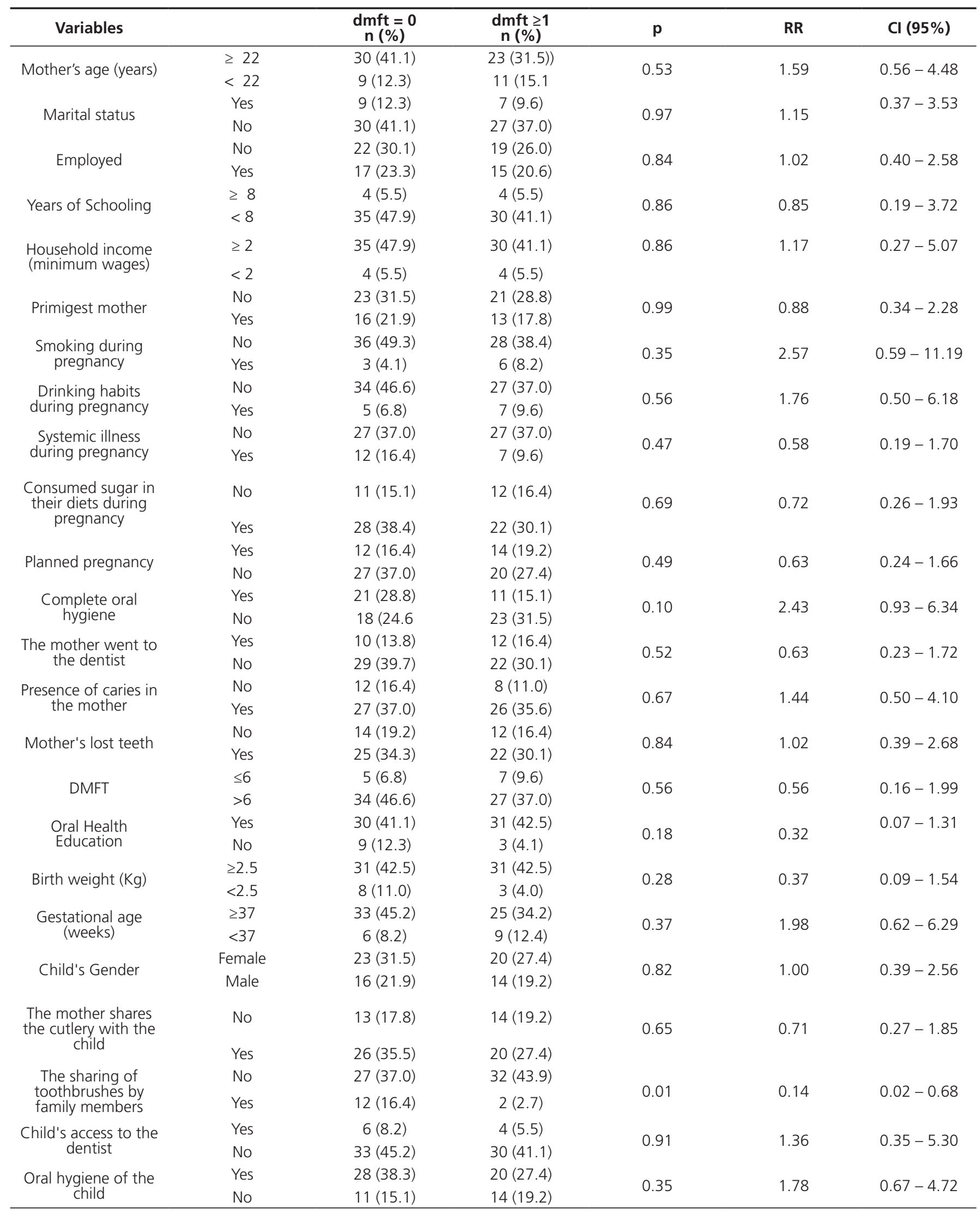




\begin{tabular}{|c|c|c|c|c|c|c|}
\hline \multirow{2}{*}{$\begin{array}{l}\text { Presence of active } \\
\text { white spots on the } \\
\text { deciduous teeth }\end{array}$} & No & 24 (32.9) & $14(19.2)$ & \multirow[b]{2}{*}{0.13} & \multirow[b]{2}{*}{2.28} & \multirow[b]{2}{*}{$0.89-5.84$} \\
\hline & Yes & $15(20.5)$ & $20(27.4)$ & & & \\
\hline \multirow{2}{*}{$\begin{array}{l}\text { Food containing } \\
\text { sugar between meals }\end{array}$} & No & $3(4.1)$ & $6(8.2)$ & \multirow{2}{*}{0.35} & \multirow{2}{*}{0.39} & \multirow{2}{*}{$0.08-1.69$} \\
\hline & Yes & $36(49.3)$ & $28(38.4)$ & & & \\
\hline \multirow{2}{*}{$\begin{array}{l}\text { Sugar in feeding } \\
\text { bottles }\end{array}$} & No & $16(21.9)$ & $14(19.2)$ & \multirow{2}{*}{0.82} & \multirow{2}{*}{0.99} & \multirow{2}{*}{$0.39-2.53$} \\
\hline & Yes & $23(31.5)$ & $20(27.4)$ & & & \\
\hline \multirow{2}{*}{$\begin{array}{l}\text { Nighttime bottles } \\
\text { with sweet liquids }\end{array}$} & No & $17(23.3)$ & $15(20.6)$ & \multirow{2}{*}{0.84} & \multirow{2}{*}{0.98} & \multirow{2}{*}{$0.38-2.47$} \\
\hline & Yes & $22(30.1)$ & $19(26.0)$ & & & \\
\hline \multirow{3}{*}{$\begin{array}{c}\text { Presence of harmful } \\
\text { habits }\end{array}$} & No & $18(24.6)$ & $21(28.8)$ & \multirow{3}{*}{0.27} & \multirow{3}{*}{0.53} & \multirow{5}{*}{$0.20-1.35$} \\
\hline & Yes & $21(28.8)$ & $13(17.8)$ & & & \\
\hline & $\leq 6$ & $18(24.7)$ & $12(16.4)$ & & & \\
\hline \multirow{2}{*}{$\begin{array}{l}\text { Breastfeeding } \\
\text { (months) }\end{array}$} & $6<12$ & $8(11.0)$ & $6(8.2)$ & \multirow{2}{*}{\multicolumn{2}{|c|}{0.48}} & \\
\hline & $\geq 12$ & $13(17.8)$ & $16(21.9)$ & & & \\
\hline
\end{tabular}

Table 4. Multiple logistical regression analysis between variables with $p \leq 0.20$ to presence of dental caries and experience of early childhood caries $(d m t f \geq 1)$ in the children. Araçatuba (SP), 2013.

\begin{tabular}{|c|c|c|c|c|c|}
\hline \multirow[t]{2}{*}{ Variables } & $\mathbf{p}$ & Coef. & Standard error & $\mathbf{R R}$ & $\mathrm{Cl}(95 \%)$ \\
\hline & \multicolumn{5}{|c|}{ presence of dental caries } \\
\hline Oral Health Education & 0.18 & -1.51 & 1.14 & 0.22 & $0.02-2.07$ \\
\hline Complete oral hygiene & 0.28 & -0.72 & 0.68 & 0.48 & $0.13-1.84$ \\
\hline Smoking during pregnancy & 0.31 & 0.97 & 0.98 & 2.64 & $0.39-17.96$ \\
\hline Drinking habits during pregnancy & 0.50 & 0.60 & 0.89 & 1.82 & $0.31-10.59$ \\
\hline Absence of harmful habits & 0.04 & -1.32 & 0.66 & 0.26 & $0.07-0.98$ \\
\hline Longer breastfeeding time & 0.14 & 0.03 & 0.02 & 1.03 & $0.99-1.09$ \\
\hline Variables & & & $d m t f \geq 1$ & & \\
\hline \multirow{3}{*}{$\begin{array}{l}\text { Complete oral hygiene } \\
\text { Presence of active white spots on the } \\
\text { deciduous teeth } \\
\text { No sharing of toothbrushes by family } \\
\text { members }\end{array}$} & 0.31 & -0.55 & 0.55 & 0.57 & $0.19-1.70$ \\
\hline & 0.25 & 0.63 & 0.54 & 1.89 & $0.65-5.54$ \\
\hline & 0.02 & -1.92 & 0.82 & 0.15 & $0.03-0.73$ \\
\hline
\end{tabular}

\section{DISCUSSION}

In this longitudinal study with a follow-up of the mother/child pairing, from gestation to the child's fourth birthday, it was found that the presence of dental caries in children was associated with the presence of deleterious habits (pacifier or thumb sucking). The experience of early childhood caries (deft $\geq 1$ ) was associated with the sharing of toothbrushes by family members.

The advantages of longitudinal studies with repeated data collection during pregnancy and infancy include the reduced bias risk resulting in the ability of the parents to faithfully record the events ${ }^{7}$. Few longitudinal studies have been conducted in a very young population, i.e. early infancy ${ }^{8}$, as is the case of this study.

Parents' attitudes and perceptions have been investigated in the prevention of early childhood caries $^{12}$. The health and welfare of children and youngsters is dependent on the practices and beliefs of the main carer, thus various psychosocial and behavioral factors of early childhood caries differ from the factors for dental caries in older children ${ }^{13}$.

The mother is deemed to be the person mainly responsible for the health of the family, principally in terms of the provision of care for their children ${ }^{24}$. As well as being able to transmit bacteria that cause caries in their children ${ }^{8}$, she also installs habits, models, values and attitudes ${ }^{6}$. Therefore, early maternal intervention can reduce the probability of early childhood caries $^{6}$ and should already be prioritized in the health services in the prenatal period ${ }^{7}$. However there are some mothers who are not interested in finding out what is best for their children's health ${ }^{10}$, necessitating greater motivation and guidance during this period.

In this study, the mothers' level of schooling was not associated with the presence of childhood caries, but 
this may be explained by the fact that the sample is very homogeneous (having similar social characteristics), i.e. the pregnant women who frequented public health services had, for the most part, a low level of schooling and low income. This finding was also noted in a separate study conducted with mothers of schoolchildren in an oral health program with homogeneous characteristics in the study population ${ }^{25}$ and it can be seen that the results differ when the study involves a heterogeneous population ${ }^{14}$.

Oral cleansing practices are heavily influenced by family circumstances, which determine the formation of either positive or harmful habits, as far as oral health is concerned. The results did not show a significant relationship between the mother's and child's oral hygiene. One hypothesis for this was the method employed to collect the data: the interview. People tend to respond what they believe to be ideal or appropriate, often omitting what really takes place, mainly with regard to oral hygiene, in order to avoid being judged by others ${ }^{26}$.

Parents or guardians still attribute little value to the importance of the deciduous dentition ${ }^{15}$. In this study, a large number of children had caries and only 10 had been seen by a dental surgeon by the age of 4 , alarming data as the first dental examination is recommended at the time of the eruption of the first tooth, and no later than 12 months of age ${ }^{4}$.

The duration of breastfeeding was linked to the presence of caries $(p=0.01)$ in the bivariate analysis, similar to the findings of another study ${ }^{27}$, however in the multiple logistic regression $(p=0.14)$ this association was not substantiated. Feeding patterns in infancy, such as prolonged breastfeeding, are responsible for an increase in the exposure of deciduous teeth to fermentable carbohydrates, and may promote the early colonization of microorganisms that cause the disease, promoting the development of caries, however a recent study did not support this association ${ }^{17}$. It is important to stress that dental caries is a multifactorial disease, thus one variable by itself is not responsible for the cause of the disease. Moreover, if the correct cleaning of the children's teeth occurs on a daily basis, eliminating bacterial plaque, there is no possibility of caries disease developing. Breastfeeding until the child is two or more years old is recommended on account of the advantages that it brings to the general and oral health of the child ${ }^{17-18}$, therefore it is not necessary to recommend the discontinuance of this form of feeding but rather to prioritize the mothers that breastfeed for a prolonged period for inclusion in the caries disease prevention groups, instructing them on how to care for their child's oral health.

The establishment of deleterious habits, such as sucking pacifiers or thumbs, was found to have significant association with the presence of caries in children in the study, both for the bivariate analysis $(p=0.01)$ and the logistic regression $(p=0.04)$, a fact which may be explained by the transmissibility of microorganisms present in these implements, besides the fact that the mother often places sweet substances on the pacifier for the child to calm down, suggesting a risk factor for dental caries ${ }^{11}$.

The brushing of the teeth is the oral hygiene measure most commonly used in the various populations, however it can be responsible for the transmission of infectious and parasitic diseases, mainly caries bacteria, if the toothbrush is shared by several people ${ }^{28}$. In this study, one important finding suggests that the non-sharing of brushes was associated with the prevention of early childhood caries ( $p=0.02 ; O R=0.15$ ). This shows that parents need to be educated about this habit, one which seems innocuous but is practiced a lot by carers, and it can lead to damage to their children's oral health.

The establishment of caries disease requires that social and cultural factors related to the primary biological, genetic and hygiene factors be in evidence. When analyzing the individual risk of caries in a child, it is necessary to evaluate the data related to his/her social interaction and environment ${ }^{16,22,26}$. It is important to include the mother's data in the child's treatment as she is the reference for the child in matters of health. Data such as mother's age at the time she gave birth to the child, her level of education, marital status, number of children, access to services, place where she lives, habits and maternal lifestyle, amongst others, need to be collected and evaluated ${ }^{29}$, as they could interfere with the child's oral condition ${ }^{30}$. It is a question of transmissibility, understood not only in the microbiological context but also, and more importantly, in the broad social, cultural and behavioral relationship of the complex etiology of caries disease ${ }^{12}$.

In the present study, mothers and children who had dental caries or periodontal problems were referred for dental treatment and oral health education meetings.

The limitations of this study must be stated. The selection of the sample purely within the public health services may have been one limitation as it results in a sample with homogeneous social characteristics. The sample, after four years of monitoring, was reduced, due to the withdrawal of mothers over the course of the study, which may be considered a follow-up bias. Even so, the 
results produced valuable findings worthy of consideration due to the scientific evidence gathered in this type of study, as it is a longitudinal type of study and possible to evaluate the incidence of the disease in a specific period of time ${ }^{19}$. Multicentric studies are required to clarify if the results are common to other larger areas and populations with different characteristics. In future studies, ways should be included to ascertain the bacterial plaque index in the teeth of both mother and infant as well as a microorganism count.

\section{CONCLUSIONS}

The results show that the behavioral aspects of the mother, such as the sharing of toothbrushes by family members and the child and the existence of non-nutritive sucking habits, have an impact on the development and experience of early childhood caries.

Accordingly, there is a need for the planning of preventive actions during the prenatal period concerning the promotion of oral health in the family context and the discouraging of the introduction of artificial teats in daily

\section{REFERENCES}

1. Kassebaum NJ, Bernabé E, Dahiya $M$, Bhandari B, Murray CJ, Marcenes W. Global burden of untreated caries: a systematic review and metaregression. J Dent Res. 2015;94(5):650-8. doi: $10.1177 / 0022034515573272$

2. Brasil. Ministério da Saúde. Coordenação Nacional de Saúde Bucal da População Brasileira. Projeto SB Brasil 2010: principais resultados. Brasília (DF): Ministério da Saúde; 2011 [citado 2016 Mar 10]. Disponível em: < http://dab.saude.gov.br/CNSB/sbbrasil/arquivos/ projeto_sb2010_relatorio_final.pdf>.

3. Niji R, Arita K, Abe $Y$, Lucas ME, Nishino M, Mitome M. Maternal age at birth and other risk factors in early childhood caries. Pediatr Dent. 2010;32(7):493-8.

4. American Academy of Pediatric Dentistry. Policy on Early Childhood Caries (ECC): Classifications, Consequences, and Preventive Strategies. Oral Health Policies. 2014;33(6):50-52.

5. Fisher-Owens SA, Gansky SA, Platt LJ, Weintraub JA, Soobader M, Bramlett MD, et al. Influences on children's oral Health: a conceptual model. Pediatrics. 2007:120(3):e510-20.

6. Leong PM, Gussy MG, Barrow SY, Silva-Sanigorski A, Waters E. A systematic review of risk factors during first year of life for early childhood caries. Int J Paediatr Dent. 2013;23(4):235-50. doi: 10.1111/j.1365-263X.2012.01260.x

7. Wigen TI, Wang NJ. Maternal health and lifestyle, and caries experience in preschool children. A longitudinal study from pregnancy to age 5 yr. Eur J Oral Sci. 2011;119(6):463-68. doi: 10.1111/j.1600-0722.2011.00862.x routine after the birth of the children.

\section{Acknowledgments}

The authors would like to thank FAPESP (the São Paulo Research Foundation) for its financial support of the research study no. 2006/61615-9 and to CAPES (Coordination for the Improvement of Higher Education Personnel) for the doctoral grant.

\section{Collaborators}

NB ROCHA participated in literature review, study design, analysis and discussion of results, and contributed to the manuscript; O SALIBA participated in data analysis; CAS GARBIN and AJl GARBIN participated in data analysisand discussion and contributed to manuscript revision; SAS MOIMAZ conceived and coordinated the study, participated in data analysis and discussion and wrote and reviewed the manuscript. All listed authors contributed significantly to the study and manuscript.

8. Zhou Y, Yang JY, Lo ECM, Lin HC. The Contribution of life course determinants to early childhood caries: a 2-Year cohort study. Caries Res. 2012;46(2):87-94. doi: 10.1159/000335574

9. Moimaz SAS, Fadel CB, Lolli LF, Garbin CAS, Garbin AJÍ, Saliba NA Social aspects of dental caries in the context of mother-child pairs. J Appl Oral Sci. 2014;22(1):73-8. doi: 10.1590/1678-775720130122

10. Moimaz SAS, Garbin CAS, Garbin AJl, Lima AMC, Lolli LF, Saliba $O$. Risk factors in the mother-child relationship that predispose to the development of early childhood caries. Eur Arch Paediatr Dent. 2014;15(4):245-250. doi: 10.1007/s40368-014-0108-1

11. Plonka KA, Pukallus ML, Barnett AG, Holcombe TF, Walsh $\amalg$, Seow WK. A longitudinal case-control study of caries development from birth to 36 months. Caries Res. 2013;47(2):117-27. doi: $10.1159 / 000345073$

12. Weatherwax JA, Bray KK, Willians KB, Gadbury-Amyot CC Exploration of the relationship between parent/guardian sociodemographics, intention, and knowledge and the oral health status of their children/wards enrolled in a Central Florida Head Start Program. Int J Dent Hyg. 2015;13(1):49-55

13. Knevel RJM, Gussy M. Case study: caries in young children. Int J Dent Hyg. 2012;10(3):181-186

14. Peres KG, Peres MA, Demarco FF, Gigante DP, Horta BL, Menezes $A M B$, Hallal PC. A saúde bucal nas coortes de nascimentos de Pelotas, RS, Brasil. Rev Bras Epidemiol. 2014;17(1):281-284. doi: 10.1590/1415-790X201400010022

15. Müller IB, Castilhos ED, Camargo MBJ, Gonçalves H. Experiência de cárie e utilização do serviço público odontológico por escolares: estudo descritivo em Arroio do Padre, Rio Grande do Sul, 2013. 
Epidemiol Serv Saúde. 2015;24(4): 759-770. 10.5123/S167949742015000400018

16. Cagnani A, Barros AMS, Sousa LLA, Oliveira AMG, Zanin L, Flório FM. Association between preference for sweet foods and dental caries. RGO, Rev Gaúch Odontol. 2014;62(1):2529.

17. Neves PAM, Ribeiro CCC, Tenuta LMA, Leitão TJ, MonteiroNeto $V$, Nunes AMM, Cury JA. Breastfeeding, Dental Biofilm Acidogenicity, and Early Childhood Caries. Caries Res. 2016:50:319-324. doi: 10.1159/000445910

18. Rocha NB, Garbin AJl, Garbin CAS, Saliba O, Moimaz SAS. A longitudinal study on breastfeeding and factors related to early weaning. Pesq Bras Odontoped Clin Integr. 2013;13(4):337-42.

19. Victora CG, Araújo CLP, Menezes AMB, Hallal PC, Vieira MF, Neutzling MB, et al. Methodological aspects of the 1993 Pelotas (Brazil) birth cohort study. Rev Saúde Pública. 2006; 40(1):3946. doi: 10.1590/S0034-89102006000100008

20. World Health Organization. Oral health surveys: basic methods. 4th ed. Geneva: World Health Organization; 1997.

21. Ainamo J, Bay I. Problems and proposals for recording gingivitis and plaque. Int Dent J. 1975;25(4):229-35.

22. Center for Disease Control and Prevention. Programa Epi Info: Versão 7.0. [programa computador] [citado 2015 Nov 21]. Disponível em: <http://www.cdc.gov/epiinfo/>.

23. Ayres M, Ayres M Jr, Ayres DL, Santos AS. Programa BioEstat [programa de computador] Version 5.0.3. [citado 2015 Nov 21]. Disponível em: <http://www.mamiraua.org.br/download/index. php?dirpath=./BioEstat\%205\%20Portugues\&order=0>.

24. Fadel CB, Saliba NA, Moimaz SAS. Mother-child relation: an interdisciplinary approach and their unfoldings for dentistry. Arq Odontol. 2008;44(3):42-8.
25. Choi HS, Ahn HY. Effects of mothers involved in dental health program for their children. J Korean Acad Nurs. 2012; 42(7):1050-61. doi: 10.4040/jkan.2012.42.7.1050

26. Rocha NB, Moimaz SAS, Garbin AJl, Saliba O, Garbin CAS Relationship between Perception of Oral Health, Clinical Conditions and Socio-Behavioral Factors of Mother-Child. Braz Res Pediatric Dent Integrated Clinic. 2015;15(1):113-121.

27. Valaitis R, Hesch R, Passarellia C, Sheehan D, Sinton J. A systematic review of the relationship between breastfeeding and early childhood caries. Can J Publ Health. 2000;91(6):411-7.

28. Ferreira CA, Savi GD, Panatto AP, Generoso JS, Barrichello T. Microbiological evaluation of bristles of frequently used toothbrushes. Dental Press J Orthod. 2012;17(4):72-6. doi: $10.1590 /$ S2176-94512012000400016

29. Costa SM, Abreu MHNG, Vasconcelos M, Lima RCGS, Verdi M, Ferreira EF. Desigualdades na distribuição da cárie dentária no Brasil: uma abordagem bioética. Cienc Saúde Colet. 2013;18(2):461-470. doi: 10.1590/S141381232013000200017

30. Massoni ACLT, Pereira RB, Nóbrega DRM, Costa LED, Fernandes JMFA, Rosenvlatt A. Assessment of pregnant, primiparous and postpartum women's knowledge about dental caries. RGO, Rev Gaúch Odontol. 2015;63(2):145-152. 